\title{
Editorial: Dams and Wetland Biodiversity: Impacts and Mitigating Measures
}

\author{
Haipeng $\mathrm{Wu}^{1,2 *}$, Yinjun $\mathrm{Zhou}^{3}$ and Hua Zhang ${ }^{4}$ \\ ${ }^{1}$ School of Hydraulic and Environmental Engineering, Changsha University of Science and Technology, Changsha, China, \\ ${ }^{2}$ Key Laboratory of Dongting Lake Aquatic Eco-Environmental Control and Restoration of Hunan Province, Changsha, China, \\ ${ }^{3}$ Changjiang River Scientific Research Institute (CRSRI), Wuhan, China, ${ }^{4}$ Department of Engineering, Texas A\&M \\ University-Corpus Christi, Corpus Christi, TX, United States
}

Keywords: dam, wetland, biodiversity, impact, mitigating measure

\section{Editorial on the Research Topic}

\section{Dams and Wetland Biodiversity: Impacts and Mitigating Measures}

To meet energy, water and transportation needs, an incredible amount of dams have been constructed around the world. For example, only in the Yangtze River's watershed of China, over 50,000 dams were built since 1950 (Nilsson et al., 2005; Wu et al., 2019). Dams could contribute to energy and water supply, and flood protection, but they also affect aquatic ecosystems by alteration of hydrologic regime and fragmentation (Barbarossa et al., 2020). While about 50\% of the river around the world is currently changed by dam, this percentage is expected to increase to $93 \%$ because of the pending construction of about 3,700 major hydropower dams (Grill et al., 2015).

The construction and operation of dams has extensively altered global freshwater wetland ecosystems, which represent biodiversity hotspots around the world and play a crucial part in protection of biodiversity (Wu et al., 2019). Freshwater wetlands cover about $0.8 \%$ of Earth's surface, but host an excessively high diversity of species (Barbarossa et al., 2020). Freshwater wetlands provided habitat for about one fifth of species (particularly the endangered and endemic species) and one third of vertebrate species in the world (Wu et al., 2019).

The aim of this Research Topic is to gather the latest research addressing the critical issue of the impact of construction, operation and removal of dams on biodiversity, with a particular focus on mitigating measures. We are convinced that the studies in this field are an essential condition for biodiversity conservation and ecological restoration in freshwater wetlands. This collection of seven papers is our humble contribution to achieve this target.

Several papers in this issue are around the subject of the direct impacts of dam on wetland biota. Crnobrnja-Isailović et al. reviewed and discussed the negatively effect of small hydropower plants' proliferation on herpetofauna in the Balkan peninsula (Southeastern Europe), where the number of small hydropower plant increased to 4,556 in year 2020. Brasil et al. researched the impact of dams on the beta-diversity of Odonata and Heteroptera on veredas in the Brazilian Cerrado through the sampling of biological communities in 13 veredas. Wang et al. studied the effect of Three Gorges Dam on lifestyle-dependent (free-living and particle-attached communities) microbial interactions in the vicinity of the dam, based on a random matrix theory based network approach and a high-throughput sequencing of gene.

Other papers are about the impacts of dam on habitat. Zhou, Li et al. reported the influence of impoundment of Three Gorges Reservoir on streamflow, sediment load and channel morphology of Acipenser sinensis spawning ground using in situ measured data, and this study had important implications for protection of gravely endangered Chinese sturgeon. Zhou, Lu et al. simulated the 
scouring adjustment process of channel downstream of a reservoir, using the generalized flume test, to predict the effects of reservoirs on aquatic habitats. $\mathrm{Xu}$ et al. examined the hydrodynamics and algal blooms in the Xiangxi Bay (part of Three Gorges Reservoir), using the CE-QUAL-W2 model. Besides, Huang et al. analyzed the responses of water ecoenvironmental quality to manufacturing industry agglomeration in 17 cities downstream of the Three Gorges Dam.

\section{AUTHOR CONTRIBUTIONS}

HW wrote a first draft. All authors revised and approved the submitted version.

\section{REFERENCES}

Barbarossa, V., Schmitt, R. J. P., Huijbregts, M. A. J., Zarfl, C., King, H., and Schipper, A. M. (2020). Impacts of current and future large dams on the geographic range connectivity of freshwater fish worldwide. Proc. Natl. Acad. Sci. U. S. A. 117, 3648-3655. doi: 10.1073/pnas.1912776117

Grill, G., Lehner, B., Lumsdon, A. E., MacDonald, G. K., Zarfl, C., and Liermann, C. R. (2015). An index-based framework for assessing patterns and trends in river fragmentation and flow regulation by global dams at multiple scales. Environ. Res. Lett. 10:015001. doi: 10.1088/1748-9326/10/1/015001

Nilsson, C., Reidy, C. A., Dynesius, M., and Revenga, C. (2005). Fragmentation and flow regulation of the world's large river systems. Science 308, 405-408. doi: $10.1126 /$ science. 1107887

Wu, H., Chen, J., Xu, J., Zeng, G., Sang, L., Liu, Q., et al. (2019). Effects of dam construction on biodiversity: a review. J. Clean. Prod. 221, 480-489. doi: 10.1016/j.jclepro.2019.03.001

\section{FUNDING}

HW was financially supported by the Natural Science Foundation of Hunan Province (2021JJ40601) and the Scientific Research Foundation of Hunan Provincial Education Department (20B005).

\section{ACKNOWLEDGMENTS}

We are very grateful to the Editorial board and all our colleagues who submitted, reviewed, and edited manuscripts for this Research Topic.

Conflict of Interest: The authors declare that the research was conducted in the absence of any commercial or financial relationships that could be construed as a potential conflict of interest.

Publisher's Note: All claims expressed in this article are solely those of the authors and do not necessarily represent those of their affiliated organizations, or those of the publisher, the editors and the reviewers. Any product that may be evaluated in this article, or claim that may be made by its manufacturer, is not guaranteed or endorsed by the publisher.

Copyright (c) $2022 \mathrm{Wu}$, Zhou and Zhang. This is an open-access article distributed under the terms of the Creative Commons Attribution License (CC BY). The use, distribution or reproduction in other forums is permitted, provided the original author(s) and the copyright owner(s) are credited and that the original publication in this journal is cited, in accordance with accepted academic practice. No use, distribution or reproduction is permitted which does not comply with these terms. 